\title{
METODE MONITORING DAN EVALUASI STANDAR BIAYA KELUARAN
}

Niken Ajeng Lestari

Email: niken3010@gmail.com

\section{PENDAHULUAN}

\subsection{Latar belakang}

Berdasarkan ketentuan pasal 24 ayat (1) PMK No.71/PMK.02/2013 tentang Pedoman Standar Biaya, Standar Struktur Biaya, dan Indeksasi dalam Penyusunan RKA K/L, Kementerian Keuangan dan/atau $\mathrm{K} / \mathrm{L}$ diamanatkan untuk melaksanakan monitoring dan evaluasi (monev) penerapan standar biaya keluaran (SBK) sesuai dengan kewenangannya. Hingga saat ini, baik dalam pelaksanaan tugas kebijakan standar biaya maupun monev penganggaran, belum dilakukan monev yang berkenaan dengan standar biaya yang dalam hal ini adalah SBK. Di sisi lain, saat ini juga belum terdapat pengaturan yang menetapkan atau menjelaskan lebih rinci aspek apa saja yang perlu untuk dimonev.

Monev SBK perlu dilaksanakan karena selain sebagai bentuk pelaksanaan peraturan perundang-perundangan, juga penting untuk dilaksanakan dalam rangka perbaikan kebijakan penganggaran yang menjadi tugas utama dari Ditjen Anggaran. Selain itu hasil monev juga menjadi bahan pertimbangan dalam menyusun dan menetapkan SBK di tahun anggaran berikutnya sebagaimana diamanatkan dalam pasal 24 ayat (3) PMK No.71/PMK.02/2013.

Pelaksanaan monev SBK berperan penting dalam hal pengembangan kebijakan standar biaya terutama karena hingga saat ini SBK dianggap kurang penting dan kurang bermanfaat bagi beberapa kementerian negara dan lembaga (K/L). Monev SBK menjadi salah satu alat untuk menampung berbagai kritik dan saran dari $\mathrm{K} / \mathrm{L}$ yang terkait dengan pelaksanaan kebijakan SBK. Selain itu, berdasarkan amanat pasal 24 ayat (2) PMK No.71/PMK.02/2013, monev SBK dilakukan meliputi realisasi anggaran dan komponen/tahapan dari SBK.

Berdasarkan beberapa hal yang telah disebutkan di atas, dalam studi ini akan dikaji konsep monev SBK yang dinilai paling tepat atau yang dapat dilaksanakan dan sesuai dengan tujuannya. Metode yang digunakan dalam menyusun kajian ini adalah kualitatif deskriptif dengan menggali informasi dari berbagai sumber dan proses wawancara dan diskusi untuk memperoleh informasi lebih lengkap.

\subsection{Tujuan penelitian}

1. Mengetahui aspek-aspek dalam monev SBK

2. Mengetahui indikator dari setiap aspek dalam monev SBK

3. Mengetahui tahapan monev SBK

\subsection{Pertanyaan penelitian}

1. Apa saja aspek-aspek dalam monev SBK?

2. Apa saja indikator penilaian dari setiap aspek dalam monev SBK?

3. Bagaimana tahapan monev SBK? 


\section{TINJAUAN PUSTAKA}

\subsection{Kebijakan Penganggaran dan Standar Biaya}

Dalam penjelasan Undang-Undang Nomor 17 Tahun 2003 tentang Keuangan Negara, terdapat 3 (tiga) pilar yang diperlukan dalam sistem penganggaran, yaitu penganggaran terpadu (unified budget), kerangka pengeluaran jangka menengah (meduim term expenditure framework) dan penganggaran berbasis kinerja (performance based budgeting). Dalam rangka mewujudkan PBK, sesuai PP No. 90 Tahun 2010 tentang Penyusunan RKA K/L, diperlukan adanya 3 instrumen yaitu: indikator kinerja, standar biaya, dan evaluasi kinerja.

PBK merupakan suatu pendekatan penganggaran yang bertujuan untuk meningkatkan akuntabilitas, efisiensi, dan efektivitas dengan menekankan bahwa setiap penggunaan uang negara (anggaran) harus mempunyai nilai manfaat yang terukur bagi peningkatan kehidupan masyarakat (value of money). Dengan demikian, setiap perencanaan anggaran harus dapat dijelaskan hubungan antara biaya yang dibutuhkan dengan ekspekasi hasil yang akan dicapai dalam pengeluaran pemerintah, yang mana kegiatan (activities) yang dibiayai harus menghasilkan keluaran (output). Pada akhirnya, gabungan dari beberapa keluaran kegiatan dalam suatu program akan mendukung pencapaian hasil (outcome) yang diinginkan.

Dalam mewujudkan PBK, sistem penganggaran diimplementasikan melalui RKA K/L terdiri dari program, kegiatan, dan keluaran. Kontrak kinerja masing-masing
$\mathrm{K} / \mathrm{L}$ diukur pada tataran keluaran kegiatan. Pendekatan PBK diterapkan dengan cara mengubah pola penganggaran dari berbasis masukan (input based) ke berbasis keluaran (output based) dan berbasis hasil (outcome based). Sejalan dengan hal itu, kebijakan standar biaya keluaran yang difungsikan sebagai tulang punggung penerapan PBK juga mengalami beberapa perubahan, antara lain sebagai berikut:

1. Pengalokasian anggaran berdasarkan rencana pencapaian keluaran (output)/sub keluaran (sub output) kegiatan yang mempunyai keterkaitan dengan pelaksanaan tugas dan fungsi satuan kerja yang melekat pada struktur organisasi K/L (money follow function);

2. Fleksibilitas dalam memilih sumber data guna mencapai efisiensi dengan tetap menjaga akuntabilitas (let manager manage);

3. Orientasi pada capaian keluaran sesuai hasil yang diinginkan (output and outcome oriented); dan

4. Fokus pada maksimalisasi hasil atas penggunaan dana.

Di sisi lain, dalam penerapan PBK, SBK memiliki beberapa manfaat diantaranya adalah:

1. Memperbaiki kualitas perencanaan;

2. Mempercepat penyusunan dan penelahaan RKA K/L; dan

3. Memudahkan pelaksanaan monitoring dan evaluasi dalam pencapaian keluaran (output).

\subsection{Standar Biaya Keluaran (SBK)}

SBK adalah besaran biaya uang ditetapkan untuk menghasilkan keluaran 
(output)/sub keluaran (sub output). SBK dapat terdiri atas.

1. Indeks biaya keluaran yaitu SBK untuk menghasilkan satu volume keluaran (output), dan

2. Total biaya keluaran adalah SBK untuk menghasilkan total volume keluaran (output).

Penyusunan SBK dilakukan pada level keluaran (output)/sub keluaran (sub output) yang menjadi tugas dan fungsi $\mathrm{K} / \mathrm{L}$. Keluaran (output)/sub keluaran (sub output) yang dapat diusulkan menjadi SBK mempunyai beberapa kriteria yaitu.

1. Bersifat berulang

2. Mempunyai jenis dan satuan yang jelas serta terukur, dan

3. Mempunyai komponen/tahapan yang jelas.

SBK dalam proses penganggaran berfungsi sebagai.

1. Batas tertinggi yang besarannya tidak dapat dilampaui,

2. Referensi penyusunan prakiraan maju,

3. Bahan penghitungan pagu indikatif $\mathrm{K} / \mathrm{L}$, dan/atau

4. Referensi penyusunan SBK untuk keluaran (output) sejenis pada K/L yang berbeda.

Di sisi lain, dalam rangka pelaksanaan anggaran, SBK berfungsi sebagai estimasi yaitu prakiraan besaran biaya yang dapat dilampaui, antara lain karena perubahan komponen/tahapan dan/atau penggunaan standar biaya yang dipengaruhi harga pasar.

SBK berlaku untuk beberapa/seluruh $\mathrm{K} / \mathrm{L}$ yang penetapannya oleh Menkeu dengan terlebih dahulu berkoordinasi dengan $\mathrm{K} / \mathrm{L}$, atau juga berlaku untuk satu K/L tertentu yang penetapannya oleh Menkeu berdasarkan usulan dari pimpinan $\mathrm{K} / \mathrm{L}$ atau pejabat yang berwenang dengan mengatasnamakan pimpinan K/L. Dalam penyusunan SBK, diperlukan adanya komponen/tahapan dengan tujuan untuk mengetahui.

1. Proses pencapaian keluaran/sub keluaran yang akan dihasilkan,

2. Relevansi terhadap pencapaian keluaran/sub keluaran, baik terhadap volume maupun kualitasnya,

3. Keterkaitan dan kesesuaian antar tahapan dalam mendukung pencapaian keluaran/sub keluaran.

Secara umum, komponen/tahapan dalam pencapaian suatu keluaran/sub keluaran menggambarkan pelaksanaan fungsi manajemen yang terdiri dari.

1. Perencanaan (planning),

2. Pengorganisasian (organizing),

3. Pelaksanaan (actuating), dan

4. Monitoring, evaluasi, dan pelaporan (controlling).

\subsection{Konsep Monitoring dan Evaluasi}

Disarikan dari Subarsono dalam situs Sekretariat Kabinet, evaluasi kebijakan adalah kegiatan untuk menilai tingkat kinerja suatu kegiatan. Evaluasi baru dapat dilakukan kalau suatu kebijakan sudah berjalan cukup waktu. Sedangkan monitoring dan evaluasi menurut Kusek dan Rist (2004: 1) merupakan alat manajemen publik yang dapat digunakan oleh pembuat kebijakan dan pembuat keputusan untuk mengetahui perkembangan dan menunjukkan pengaruh dari proyek, program, atau kebijakan tertentu. 


\section{METODOLOGI PENELITIAN}

Kajian ini disusun dengan menggunakan metode kualitatif berupa telaah pustaka, antara lain: peraturan perundang-undang terkait dan sumber lainnya yang relevan dengan materi kajian.

\section{PEMBAHASAN}

\subsection{Aspek-Aspek dalam Monev SBK}

Berdasarkan amanat PMK No.71/PMK.02/2013, monev SBK meliputi realisasi anggaran dan komponen/tahapan. Selain itu, terdapat aspek lain yang penting untuk dimonev terkait dengan SBK yaitu aspek konsistensi dan pelaksanaan SBK. Berikut akan diuraikan hal-hal yang lebih rinci dari 4 aspek yang perlu dimonev dalam SBK.

1. Realisasi Anggaran

Aspek realisasi anggaran dalam kaitannya dengan monev SBK ialah membandingkan antara besaran SBK yang ditetapkan, alokasi SBK dalam RKA K/L, dan realisasi SBK. Berikut ilustrasi dari monev yang terkait dengan aspek realisasi anggaran (Gambar 1).

Gambar 1. Ilustrasi Monev SBK dari Aspek Realisasi Anggaran

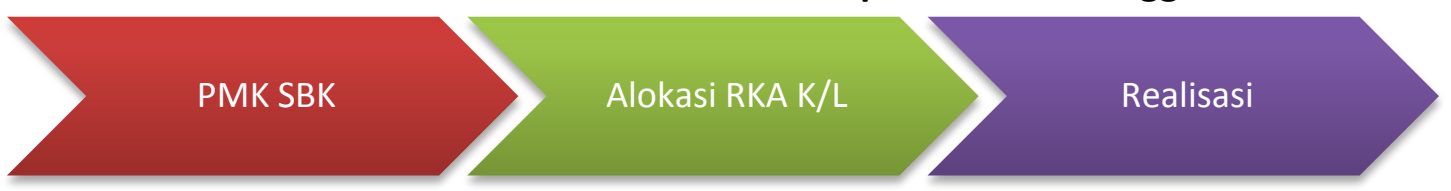

Aspek ini penting untuk dimonev dalam rangka untuk mengetahui antara kebutuhan yang sebenarnya dari suatu SBK yang telah ditetapkan. Di sisi lain, akan diketahui beberapa perilaku biaya suatu $\mathrm{K} / \mathrm{L}$ terhadap kebijakan SBK dalam proses perencanaan dan pelaksanaan anggarannya. Ilustrasi sebagai berikut akan memberikan beberapa analisis mengenai perilaku K/L terkait SBK.

Contoh kasus:

PMK SBK telah ditetapkan satuan biaya untuk menghasilkan 1 output $A$ sebesar Rp 100juta. Pada RKA K/L, alokasi output A adalah sama sebesar Rp 100juta, namun pada suatu waktu, K/L tersebut melakukan revisi anggaran yang menyebabkan sisa dana untuk output $A$ hanya sebesar $R p$ 50juta dan sisanya digeser untuk output lainnya.

Berdasarkan ilustrasi tersebut di atas, tentu saja terdapat pro dan kontra terhadap hal tersebut. Analisis yang dapat diperoleh dari kasus tersebut diantaranya adalah.

a. Hal tersebut boleh dilakukan selama output A telah tercapai. Selanjutnya pada tahun berikutnya $\mathrm{K} / \mathrm{L}$ tersebut kembali mengajukan SBK dengan besaran Rp 50juta untuk menghasilkan 1 output $A$,

b. Hal tersebut tidak boleh dilakukan karena $\mathrm{K} / \mathrm{L}$ ditengarai sengaja mengambil kesempatan untuk memperoleh alokasi anggaran yang lebih besar padahal kebutuhannya tidak sebesar yang telah ditetapkan dalam PMK SBK, dan

c. Semakin tidak dibenarkan apabila output A belum tercapai dan dana yang dialokasikan telah terserap Rp 50juta saja.

Sementara itu, jika terdapat kasus yang sebaliknya dari ilustrasi di atas, 
apabila SBK yang ditetapkan dalam PMK ternyata realisasinya lebih besar daripada yang ditetapkan, hal ini menjadi bahan review bagi penetapan SBK tahun berikutnya. SBK yang diajukan pada tahun berikutnya, dapat lebih tinggi dari tahun sebelumnya, dengan tentu saja memperhatikan realisasi SBK di tahun sebelumnya dan beberapa rincian komponen/tahapannya.

2. Komponen/Tahapan

Monev aspek komponen/tahapan SBK adalah membandingkan antara komponen/tahapan dalam menghasilkan suatu output pada saat mengusulkan SBK dengan alokasi dalam RKA K/L dan dengan realisasi SBK. Aspek ini penting untuk dimonev dalam rangka mengetahui konsistensi dalam proses perencanaan penganggaran $\mathrm{K} / \mathrm{L}$ dan pelaksanaannya. Selain itu, hasil monev komponen/tahapan dapat menjadi acuan dalam melakukan penelaahan SBK yaitu untuk menilai kesesuaian suatu usulan komponen/tahapan SBK dengan membandingkan realisasi komponen/tahapan SBK yang sama yang telah dimonev.

Komponen/tahapan SBK memang bukan merupakan bagian yang ditetapkan dalam PMK tentang SBK, namun demikian dalam proses pengajuan usulan SBK oleh K/L kepada Kemenkeu harus menyertakan pula rincian komponen/tahapan dengan tujuan untuk mengetahui.

a. Proses pencapaian output/sub output yang akan dihasilkan;

b. Relevansi teradap pencapaian output/sub output, baik terhadap volume maupun kualitasnya;

c. Keterkaitan dan kesesuaian antar tahapan dalam mendukung pencapaian output/sub output.

Maka dengan demikian, berikut ilustrasi monev SBK dari aspek komponen/tahapan (Gambar 2).

\section{Gambar 2. Ilustrasi Monev SBK dari Aspek Komponen/Tahapan}

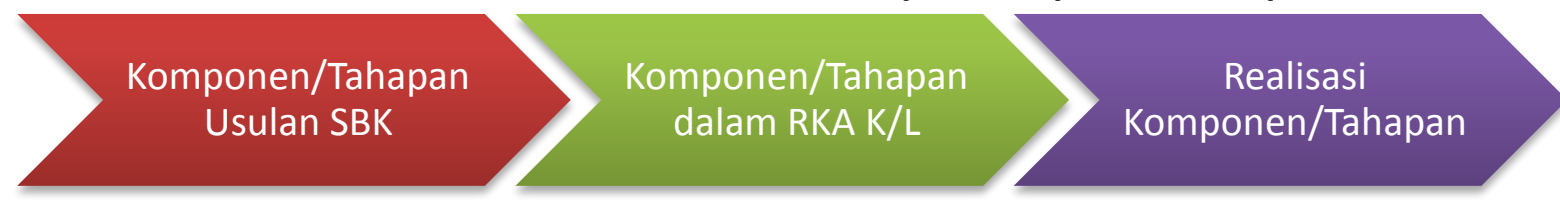

3. Konsistensi

Aspek konsistensi memang bukan merupakan salah satu aspek yang diamanatkan oleh peraturan perundangundangan untuk dimonev terkait SBK, namun hal ini dapat menjadi salah satu pertimbangan untuk dijadikan salah satu aspek yang penting untuk dimonev. Aspek konsistensi di sini adalah membandingkan antara SBK yang telah ditetapkan pada tahun $t$ dengan adanya usulan SBK pada tahun $\mathrm{t}+1$. Artinya, monev aspek konsistensi bertujuan untuk mengetahui konsistensi perilaku $\mathrm{K} / \mathrm{L}$ dalam hal mengusulkan SBK dari tahun ke tahun dengan memperhatikan beberapa hal lainnya. Selain itu, aspek konsistensi diukur juga dengan tujuan untuk mengetahui apakah SBK yang telah ditetapkan telah digunakan dalam proses penganggaran.

Terdapat berbagai opini terkait dengan SBK oleh K/L. Beberapa satker merasakan bahwa dengan adanya SBK akan mempermudah proses perencanaan penganggaran pada satkernya. Di sisi lain, justru terdapat satker yang merasa bingung output apa yang bisa diusulkan 
menjadi SBK. Hal ini mengindikasikan beberapa hal yaitu.

a. K/L kurang memahami tusi dan kewenangan unitnya yang tergambar dari munculnya kebingungan dalam merumuskan output yang sifatnya berulang yang dapat diusulkan menjadi SBK.

b. K/L kurang memahami pentingnya dan manfaat dari SBK.

c. Kurang efektifnya transfer knowledge yang dilakukan oleh pihak DJA terkait SBK.

Beberapa hal tersebut di atas, dapat menyebabkan diantaranya adalah terjadi keengganan $\mathrm{K} / \mathrm{L}$ untuk mengusulkan SBK. Selain itu, adanya perubahan nomenklatur atau pun informasi yang tidak sempurna menjadi alasan lain bagi $\mathrm{K} / \mathrm{L}$ yang tidak mengajukan SBK.

Di sisi lain, hingga saat ini terdapat pula $\mathrm{K} / \mathrm{L}$ yang telah mengajukan SBK dan ditetapkan dalam PMK namun tidak digunakan dalam proses perencanaan anggaran $\mathrm{K} / \mathrm{L}$ tersebut. Alasan $\mathrm{K} / \mathrm{L}$ melakukan hal tersebut belum diketahui namun dugaan sementara hanya untuk memenuhi permintaan dari pihak Kementerian Keuangan (Ditjen Anggaran) untuk setidaknya setiap eselon satu mengajukan 1 buah SBK.

Berdasarkan berbagai alasan tersebut, monev SBK dari aspek konsistensi bertujuan untuk menjaring informasi yang lebih lengkap mengenai konsistesi $\mathrm{K} / \mathrm{L}$ dalam mengusulkan SBK. Pada akhirnya hasil dari monev ini dapat menjadi masukan bagi DJA untuk melakukan berbagai perbaikan dalam proses bisnis penyusunan PMK SBK di tahun berikutnya.

\section{Pelaksanaan SBK}

Tujuan dari monev SBK dari aspek pelaksanaan adalah untuk menghimpun berbagai opini terkait dengan kebijakan SBK. Beberapa hal yang dipertanyakan berupa pertanyaan terbuka mengenai beberapa hal seperti proses bisnis, proses penganggaran, penelaahan, persetujuan, pelaksanaan, revisi, dan lain sebagainya.

4. Indikator Penilaian dalam Monev SBK

Sesuai dengan 4 aspek dalam monev SBK sebagaimana disebutkan di atas, terdapat masing-masing indikator yang menjadi penilaian dalam monev SBK. Pada dasarnya, setiap indikator dipilih untuk membandingkan antara SBK yang diusulkan dalam PMK dengan SBK yang digunakan dalam proses perencanaan anggaran dan pelaksanaannya. Berikut uraian indikator dari setiap aspek sebagaimana telah disebutkan di atas.

1. Indikator Realisasi Anggaran

Penghitungan yang digunakan dalam monev aspek realisasi anggaran menggunakan tehnik penghitungan sederhana yaitu dengan melihat selisih dari angka SBK antara PMK SBK, alokasi SBK pada RKA K/L, dan realisasi SBK. Berikut uraian singkatnya dan dokumen yang dibutuhkan dalam melakukan monev.

a. Perbandingan besaran PMK SBK dengan alokasi pada RKA K/L Indikator ini membandingkan antara besaran SBK yang telah ditetapkan pada PMK dengan besaran SBK yang dialokasikan dalam RKA K/L berkenaan. Maka ilustrasinya adalah sebagai berikut. 
Tabel 1. Indikator 1 dari Aspek Realisasi Anggaran

Monitoring dan Evaluasi Kebijakan Standar Biaya Keluaran

Tahun XXXX

Nama Kementerian Negara dan Lembaga: $A B C D$

\section{A. Aspek Realisasi Anggaran}

Indikator:

A.1. Perbandingan besaran PMK SBK dengan alokasi pada RKA K/L

Besaran

No. Jenis SBK pada PMK SBK pada Selisih Keterangan

Alokasi

1.

2.

Analisis SBK 1:

Analisis SBK 2:

Pada tabel di atas ditunjukkan bahwa pada indikator 1 aspek realisasi anggaran yang menjadi perhatian adalah selisih antara besaran SBK pada PMK SBK dan besaran SBK yang telah dialokasikan pada RKA K/L. Hal ini untuk mengetahui konsistensi atau perilaku $\mathrm{K} / \mathrm{L}$ dalam proses perencanaan anggaran terkait besaran SBK.

Dokumen yang digunakan dalam melakukan monev ini adalah PMK tentang SBK dan Keppres tentang Rincian Anggaran Belanja Pemerintah Pusat. Tahun dari kedua dokumen tersebut tentunya memiliki tahun anggaran yang sama misalnya PMK tentang SBK Tahun Anggaran 2015 dibandingkan dengan Keppres tentang Rincian Anggaran Belanja Pemerintah Pusat Tahun Anggaran 2015.

b. Perbandingan alokasi RKA K/L dengan realisasi anggaran Indikator ini membandingkan antara besaran SBK yang digunakan dalam alokasi RKA K/L dengan SBK pada realisasi anggaran $\mathrm{K} / \mathrm{L}$ berkenaan. Maka ilustrasinya adalah sebagai berikut. 
Tabel 2. Indikator 2 dari Aspek Realisasi Anggaran

Monitoring dan Evaluasi Kebijakan Standar Biaya Keluaran

Tahun XXXX

Nama Kementerian Negara dan Lembaga: $A B C D$

\section{A. Aspek Realisasi Anggaran}

Indikator:

A.2. Perbandingan alokasi RKA K/L dengan realisasi anggaran

Besaran

No. Jenis SBK pada alokasi $\begin{aligned} & \text { pada } \\ & \text { realisasi }\end{aligned}$

1.

2.

Analisis SBK 1:

Analisis SBK 2:

Pada tabel di atas ditunjukkan serupa dengan yang terdapat pada indikator 1 bahwa pada indikator 2 aspek realisasi anggaran yang menjadi perhatian adalah selisih antara besaran SBK yang digunakan dalam alokasi anggaran $\mathrm{K} / \mathrm{L}$ dan besaran realisasi SBK. Hal ini untuk mengetahui perbedaan besaran SBK pada saat alokasi anggaran $\mathrm{K} / \mathrm{L} \quad$ (proses perencanaan anggaran) dengan realisasinya (proses pelaksanaan anggaran).

Dokumen yang digunakan dalam melakukan monev ini adalah Keppres tentang Rincian Anggaran Belanja Pemerintah Pusat dan dokumen realisasi anggaran belanja K/L. Serupa dengan yang terdapat pada indikator 1, tahun dari kedua dokumen tersebut tentunya memiliki tahun anggaran yang sama misalnya Keppres tentang Rincian Anggaran Belanja Pemerintah Pusat tahun anggaran
2015 dan dokumen realisasi anggaran belanja $\mathrm{K} / \mathrm{L}$ tahun anggaran 2015.

2. Indikator Komponen/Tahapan

Terdapat 2 indikator dalam monev aspek komponen/tahapan SBK. Pada dasarnya untuk mengetahui konsistensi $\mathrm{K} / \mathrm{L} \quad$ usulan komponen/tahapan pada saat proses pengajuan usulan SBK dengan komponen/tahapan yang ditetapkan dalam RKA $\mathrm{K} / \mathrm{L}$ dan juga dengan realisasi anggaran belanjanya.

a. Perbandingan usulan komponen/tahapan dengan RKA $\mathrm{K} / \mathrm{L}$

Pada indikator ini membandingkan komponen/tahapan SBK yang tertuang dalam dokumen usulan SBK yang telah ditetapkan dengan komponen/tahapan SBK yang tertuang dalam dokumen anggaran yang telah disahkan dalam Perpres tentang Rincian Anggaran Belanja Pemerintah Pusat. Indikator ini bertujuan untuk mengetahui konsistensi K/L 
dalam mengajukan SBK dengan

proses perencanaan anggarannya.

Berikut ilustrasi monev SBK dengan indikator perbandingan usulan komponen/tahapan dengan RKA K/L.

Tabel 3. Indikator 1 dari Aspek Komponen/Tahapan

Monitoring dan Evaluasi Kebijakan Standar Biaya Keluaran

Tahun XXXX

Nama Kementerian Negara dan Lembaga: $A B C D$

\section{B. Aspek Komponen/Tahapan}

Indikator:

B.1. Perbandingan usulan komponen/tahapan dengan RKA K/L

Komponen/Tahapan

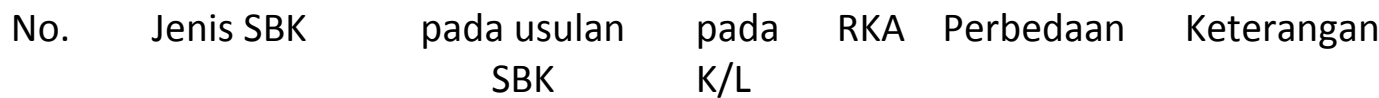

1.

2.

Analisis SBK 1:

Analisis SBK 2:

b. Perbandingan usulan komponen/ tahapan dengan realisasi

Pada indikator ini membandingkan komponen/tahapan SBK yang tertuang dalam dokumen anggaran yang telah disahkan dalam Perpres tentang Rincian Anggaran Belanja Pemerintah Pusat dengan komponen/tahapan pada dokumen realisasi anggaran. Indikator ini bertujuan untuk mengetahui konsistensi $\mathrm{K} / \mathrm{L}$ dalam proses perencanaan anggaran dengan proses pelaksanaannya. Berikut ilustrasi monev SBK dengan indikator perbandingan usulan komponen/tahapan dengan realisasi.

Tabel 4. Indikator 2 dari Aspek Komponen/Tahapan

Monitoring dan Evaluasi Kebijakan Standar Biaya Keluaran

Tahun XXXX

Nama Kementerian Negara dan Lembaga: $A B C D$

\section{B. Aspek Komponen/Tahapan}

Indikator:

B.2. Perbandingan usulan komponen/tahapan dengan realisasi

$$
\text { Komponen/Tahapan }
$$

No. Jenis SBK pada RKA K/L $\begin{aligned} & \text { pada } \\ & \text { realisasi }\end{aligned}$
1.

2.

Analisis SBK 1:

Analisis SBK 2: 
3. Indikator Konsistensi

Pada indikator ini yang dimonev adalah berkenaan dengan SBK dalam proses pengajuan PMK hingga proses perencanaan penganggaran. Namun yang menjadi perhatian pada aspek ini bukan besaran SBKnya tapi jumlah SBK, jenis output/sub output, dan penggunaan SBK dalam RKA K/L baik dilihat dari jumlah yang dipakai maupun jenis output/sub output. Berikut beberapa uraian indikator dari aspek konsistensi. a. Perbandingan jumlah SBK dalam PMK SBK berdasarkan waktu Pada indikator pertama ini membandingkan banyaknya SBK suatu $\mathrm{K} / \mathrm{L}$ yang telah ditetapkan dalam PMK SBK pada tahun $\mathrm{t}$ dengan jumlah SBK dari $K / L$ yang sama dalam PMK SBK di tahun $\mathrm{t}+1$. Berikut ilustrasi monev perbandingan jumlah PMK SBK berdasarkan waktu.

Tabel 5. Indikator 1 dari Aspek Konsistensi

Monitoring dan Evaluasi Kebijakan Standar Biaya Keluaran

Tahun XXXX

Nama Kementerian Negara dan Lembaga: ABCD

\section{Aspek Konsistensi}

Indikator:

C.1. Perbandingan jumlah SBK dalam PMK SBK berdasarkan waktu No

Indikator

PMK SBK

Tahun $\mathrm{t} \quad$ Tahun $\mathrm{t}+1$

Perbedaan

Keteranga

$\mathrm{n}$

1. Jumlah SBK

Analisis:

b. Perbandingan SBK berdasarkan PMK SBK tahun $t$ dengan PMK SBK jenis output/sub output Pada indikator kedua ini membandingkan jenis output/sub tahun $\mathrm{t}+1$. Berikut ilustrasi monev perbandingan SBK berdasarkan output yang diusulkan $\mathrm{K} / \mathrm{L}$ pada jenis output/sub output. 
Tabel 6. Indikator 2 dari Aspek Konsistensi

Monitoring dan Evaluasi Kebijakan Standar Biaya Keluaran

Tahun XXXX

\section{Aspek Konsistensi}

Nama Kementerian Negara dan Lembaga: $A B C D$

Indikator:

C.2. Perbandingan SBK berdasarkan jenis output/sub output

No

Indikator

PMK SBK

Tahun $\mathrm{t}$ Tahun $\mathrm{t}+1$

Perbedaan Keterangan

$\begin{array}{llll}\text { 1. Jenis output/sub } & \text { a. SBK A } & \text { a. SBK A } \\ \text { output } & \text { b. SBK B } & \text { b. SBK C } \\ & \text { c. } \ldots & \ldots & \end{array}$

Analisis:

c. Penggunaan SBK dalam RKA K/L

Indikator ini bertujuan untuk mengetahui perilaku $\mathrm{K} / \mathrm{L}$ dalam hal penggunaan SBK dalam proses perencanaan anggarannya. Indikator ini muncul karena terdapat kenyataan bahwa SBK yang telah ditetapkan dalam PMK ternyata tidak digunakan $\mathrm{K} / \mathrm{L}$ dalam proses penyusunan dokumen anggarannya. Berikut ilustrasi monev penggunaan SBK dalam RKA K/L.

Tabel 7. Indikator 3 dari Aspek Konsistensi

Monitoring dan Evaluasi Kebijakan Standar Biaya Keluaran

Tahun XXXX

\section{Aspek Konsistensi}

Nama Kementerian Negara dan Lembaga: $A B C D$

Indikator:

C.3. Penggunaan SBK dalam RKA K/L

No

Indikator Jenis SBK Digunakan dalam RKA K/L Keterangan

1. Penggunaan SBK
a. SBK $A$
a. Ya
b. SBK B
b. Tidak
c. $\ldots$

Analisis:

d. Penggunaan jumlah SBK dalam

indikator ini yang menjadi RKA K/L

perhatian adalah antara jumlah

Serupa dengan indikator 3 di atas, SBK yang ditetapkan dalam PMK indikator ini bertujuan untuk dengan banyak SBK yang mengetahui penggunaan SBK digunakan dalam RKA K/L. Berikut 
ilustrasi monev penggunaan

jumlah SBK dalam RKA K/L.

Tabel 8. Indikator 4 dari Aspek Konsistensi

Monitoring dan Evaluasi Kebijakan Standar Biaya Keluaran

Tahun XXXX

Nama Kementerian Negara dan Lembaga: $A B C D$

\section{Aspek Konsistensi}

Indikator:

C.4. Penggunaan jumlah SBK dalam RKA K/L

No

Indikator
dalam RKA K/L

Jumlah SBK

1. Penggunaan jumlah
SBK dalam RKA K/L

$\begin{array}{ccccc}\text { Dalam } & \text { Dalam } \\ \text { PMK } & \text { K/L } & & \text { Perbedaan } & \begin{array}{c}\text { Keteranga } \\ n\end{array}\end{array}$

Analisis:

5. Tahapan Monev SBK

Pada tahapan monev SBK ini akan diuraikan pihak-pihak yang terlibat dan beberapa aktivitas yang dilakukan dalam pelaksanaan monev SBK. Beberapa pihak yang terlibat tentu saja tidak berbeda dengan pihak-pihak yang terlibat dalam proses penyusunan SBK. Beberapa tahap utama dalam pelaksanaan monev SBK serupa dengan pelaksanaan monev lainnya yaitu.

1. Persiapan,

Pada tahap persiapan ini, pihak-pihak yang terlibat masih dalam lingkup internal Direktorat Jenderal Anggaran yaitu Direktorat Anggaran I, II, dan III dan Direktorat Sistem Penganggaran. Pada tahap awal Direktorat Sistem Penganggaran melakukan bimbingan teknis mengenai hal-hal penting terkait monev SBK mulai dari tujuan monev, manfaat monev, aspek-aspek yang dimonev, indikator-indikator yang diukur, data yang diperlukan, dan bentuk pelaporannya. Dalam kesempatan ini dilakukan internalisasi secara maksimal agar pentingnya dan manfaat dari monev SBK maupun SBK sendiri dapat benar-benar dipahami bersama oleh Direktorat Anggaran mengingat yang akan melakukan monev adalah Direktorat tersebut.

Selain itu, perihal monev SBK juga perlu disampaikan pada beberapa kesempatan sosialisasi kebijakan yang diterbitkan oleh Direktorat Sistem Penganggaran kepada K/L diantaranya sosialisasi juknis RKA $\mathrm{K} / \mathrm{L}$ dan kebijakan standar biaya yang disampaikan pada awal tahun anggaran. Penyampaian informasi ini dilakukan untuk memberi $\mathrm{K} / \mathrm{L}$ informasi terlebih dahulu di awal tahun penganggaran agar $\mathrm{K} / \mathrm{L}$ dapat lebih mempersiapkan diri baik dalam ketersedian waktunya, penyediaan datanya, dan pelaporannya.

2. Pelaksanaan,

Pada tahap pelaksanaan, pihak-pihak yang terkait sudah melibatkan 2 pihak 
yaitu Direktorat Anggaran dan K/L yang menjadi mitra kerjanya. Pada tahap ini Direktorat Anggaran menentukan satker $\mathrm{K} / \mathrm{L}$ yang akan dimonev. Selanjutnya Direktorat Anggaran melakukan koordinasi awal kepada setiap $\mathrm{K} / \mathrm{L}$ bahwa akan dilakukan monev SBK dengan berbagai keperluan yang harus disiapkan. Pada kesempatan selanjutnya, setiap $\mathrm{K} / \mathrm{L}$ diminta untuk menjawab berbagai pertanyaan yang diajukan dalam kuesioner monev SBK dan menyampaikannya kepada Direktorat Anggaran. Pada proses ini diharapkan terdapat dukungan teknologi informasi untuk membantu kemudahan dan kelancaran monev. Aplikasi monev diharapkan dapat terintegrasi dengan aplikasi SBK yang telah ada sehingga ke depannya terdapat bank data SBK yang dapat digunakan dalam rangka penelaahan
SBK dan penyusunan SBK tahun berikutnya.

3. Pelaporan.

Pada tahap ini Direktorat Anggaran melakukan analisis terhadap hasil monev dari masing-masing $\mathrm{K} / \mathrm{L}$ yang menjadi mitra kerjanya. Hasil monev selanjutnya disampaikan kepada pihak eksternal DJA yaitu pimpinan $\mathrm{K} / \mathrm{L}$ dan juga pihak internal DJA yaitu Dirjen Anggaran dengan tembusan ke Direktorat Sistem Penganggaran. Hasil monev selain dapat menjadi bahan penelaahan atau penyusunan SBK tahun berikutnya, juga dapat menjadi bahan masukan dalam menyusun kebijakan SBK di tahun yang akan datang.

Berdasarkan uraian proses bisnis pelaksanaan monev SBK di atas, berikut ilustrasi proses bisnis tersebut yang disajikan dalam bentuk flowchart sederhana. 
Gambar 3. Alur Sederhana Proses Bisnis Monev SBK

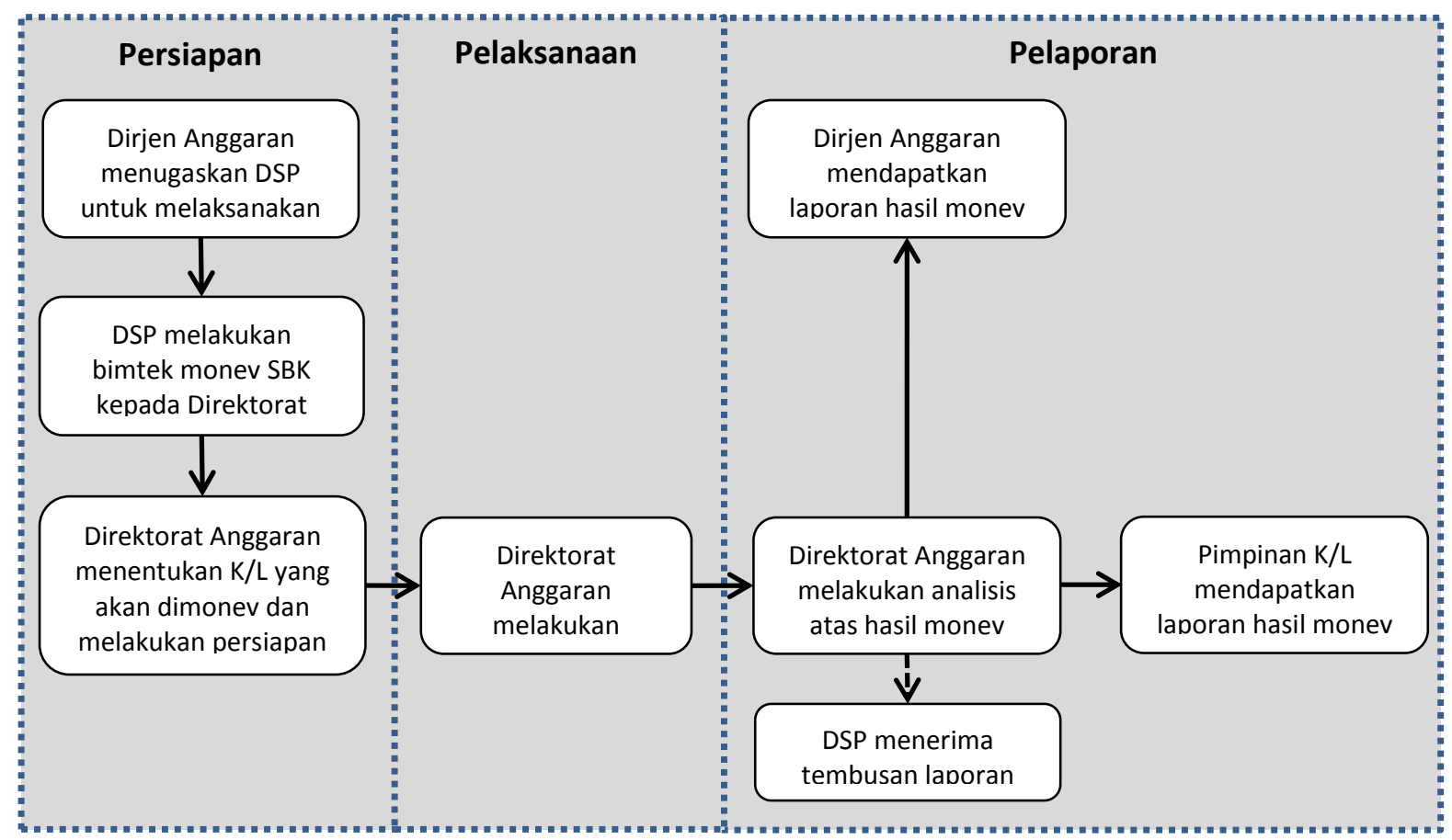

\section{KESIMPULAN DAN SARAN}

\subsection{Kesimpulan}

Berdasarkan kajian di atas, dapat beberapa kesimpulan yang dapat diperoleh yaitu.

1. Tujuan dan manfaat dilakukannya monev SBK adalah

a. Bahan penyusunan SBK bagi $\mathrm{KL}$ maupun Kementerian Keuangan dalam penelaahan SBK tahun berikutnya,

b. Alat untuk mengetahui perilaku biaya (cost behaviour) K/L khususnya terkait dengan SBK, dan

c. Memperoleh feedback dari K/L dan mengetahui keinginan $\mathrm{K} / \mathrm{L}$ atas suatu kebijakan dan pelaksanaan SBK.

2. Terdapat 4 aspek dalam monev SBK diantaranya adalah.

a. Realisasi anggaran,
b. Komponen/tahapan,
c. Konsistensi, dan
d. Pelaksanaan.

3. Dari 4 aspek monev SBK tersebut, terdapat indikator dari masing-masing aspek yaitu.

a. Realisasi anggaran,

1) Perbandingan besaran PMK SBK dengan alokasi pada RKA $\mathrm{K} / \mathrm{L}$

2) Perbandingan alokasi RKA K/L dengan realisasi anggaran

b. Komponen/tahapan,

1) Perbandingan usulan komponen/tahapan dengan RKA K/L

2) Perbandingan usulan komponen/tahapan dengan realisasi

c. Konsistensi, dan

1) Perbandingan jumlah SBK dalam PMK SBK berdasarkan waktu 
2) Perbandingan SBK berdasarkan jenis output/sub output

3) Penggunaan SBK dalam RKA $\mathrm{K} / \mathrm{L}$

4) Penggunaan jumlah SBK dalam RKA K/L

d. Pelaksanaan.

Pada aspek ini hanya akan terdapat beberapa pertanyaan terbuka mengenai beberapa hal seperti proses bisnis, proses penganggaran, penelaahan, persetujuan, pelaksanaan, revisi, dan lain sebagainya.

4. Tahapan monev SBK dibagi menjadi 3 pokok kegiatan utama yaitu

a. Persiapan

Pada tahap kegiatan ini pada dasarnya terdapat koordinasi antara DSP dengan Direktorat Anggaran yaitu DSP melakukan bimtek kepada Direktorat Anggaran mengenai monev SBK dan Direktorat Anggaran mulai melakukan identifikasi $\mathrm{K} / \mathrm{L}$ yang akan dimonev sesuai dengan pembagian mitra kerjanya.

b. Pelaksanaan

Pada tahap ini Direktorat Anggaran melakukan monev kepada $\mathrm{K} / \mathrm{L}$ dengan meminta $\mathrm{K} / \mathrm{L}$ mengisi beberapa kuesioner dan melengkapi beberapa yang diperlukan dalam pelaksanaan monev.

c. Pelaporan

Pada tahap ini Direktorat Anggaran melakukan analisis atas hasil monev SBK yang dilengkapi oleh K/L kemudian melaporkan hasil monev kepada Pimpinan KL dan Dirjen Anggaran dengan tembusan kepada Direktorat Sistem Penganggaran.

\subsection{Saran}

Dalam pelaksanaan monev SBK, terdapat beberapa saran yang dapat diberikan agar monev dapat dilaksanakan secara lancar dan tujuan monev dapat tercapai sesuai yang diharapkan.

1. Pentingnya peran SBK dalam proses penganggaran diharapkan dapat dipahami oleh semua pihak di lingkungan Kementrian Keuangan khususnya Direktorat Jenderal Anggaran, mulai dari level pimpinan yang tertinggi hingga pelaksana.

2. Dalam rangka mendukung kelancaran pelaksanaan SBK, diperlukan dukungan tehnologi informasi berupa aplikasi atau hal lainnya sehingga monev mudah dilaksanakan dan tidak membebani DJA maupun $\mathrm{K} / \mathrm{L}$.

3. Metode monev SBK perlu ditetapkan dalam bentuk peraturan perundangundangan sehingga dapat memiliki kekuatan hukum yang tetap.

\section{DAFTAR PUSTAKA}

Kusek, Jody Zall Kusek dan Ray C. Rist. 2004. Ten Steps To A Results-Based Monitoring And Evaluation System : a handbook for development practitioners. World Bank. Washington DC.

Undang-Undang Nomor 17 Tahun 2003 tentang Keuangan Negara

Peraturan Pemerintah Nomor 90 Tahun 2010 tentang Penyusunan Rencana Kerja Anggaran Kementerian Negara dan Lembaga 
Peraturan Menteri Keuangan Nomor 71/PMK.02/2013 tentang Pedoman Standar Biaya, Standar Struktur
Biaya, dan Indeksasi dalam Penyusunan RKA K/L 